\title{
General Characteristics of Korean Propolis
}

\author{
Soon Ok Woo*, Sang Mi Han, Inpyo Hong, Yong Soo Choi, Kwang Gill Lee, Joo Hong Yeo, Hae Yong \\ Kweon, Myoung Ryeol Lee, and Man Young Lee \\ Department of Agricultural Biology, National Academy of Agricultural Science(NAAS), Rural Development Administra- \\ tion(RDA), Suwon, 441-853, Korea
}

(Received 6 November 2012; Accepted 3 January 2013)

The propolis was collected from the whole part of Korea Peninsula, such as central, southern, and Jeju island, to analyze the general composition including total flavonoid and phenolic contents, heavy metals, colors, amino acids, and crude lipid. The total flavonoid and phenolic contents of middle region in Korea Peninsula (4.26\% and $13.06 \mathrm{~g} / 100 \mathrm{~g}$ gallic acid) were higher than southern region $(2.53 \%, 10.9 \mathrm{~g} / 100 \mathrm{~g}$ gallic acid) and Jeju island $(0.03 \%, 7.22 \mathrm{~g} / 100 \mathrm{~g}$ gallic acid), respectively. The heavy metals contents showed that $\mathrm{Zn}$ contents were found in $0.44 \pm 0.2 \mathrm{ppm}$ and a harmful heavy metal such as $\mathrm{Cr}, \mathrm{Cd}, \mathrm{Pb}, \mathrm{Ni}, \mathrm{Cu}, \mathrm{As}$, and $\mathrm{Hg}$ were not detected at all in our experiment. The colors of extracted propolis showed a various spectrum from yellow to red purple. Various amino acids were also detected as proline, valine, methionine and the average crude lipid contents of propolis were 42.4\%. All data collected in South Korea were very first executed in our institution for the purposes of utilizing and developing the industrial insects, honeybees as well as silkworm.

Key words: Propolis, Characteristics, South Korea, Flavonoids, Phenolics

\section{Introduction}

Propolis, or 'bee glue', is a complex resinous mixture of plant-derived products gathered, modified and used by

\footnotetext{
*To whom the correspondence addressed

Department of Agricultural Biology, National Academy of Agricultural Science(NAAS), Rural Development Administration(RDA), Suwon, 441-853, Korea

Tel: 031-290-8508, 290-8516, E-mail:wooso1@korea.kr http://dx.doi.org/10.7852/ijie.2012.25.2.209
}

bees as a general purpose sealer, draught excluder and antibiotic in their hives. Propolis typically consists of waxes, resins, water, inorganics, phenolics and essential oils, the exact composition of which is dependent upon the source plant(s). The presence of propolis within the hive may also provide an environment not suitable for the growth of bacteria and other microorganisms. Propolis composition is directly related to that of bud exudates collected by bees from various trees (Mochida et al., 1985). The geographical dependence of propolis constituents is exemplified in analyses of, e.g. European, South American, Chinese, Canadian and Spanish sourced samples. Very little work has been carried out on the quantification of individual propolis components. Propolis in general contains a variety of chemical compounds such as polyphenols (flavonoid aglycones, phenolic acids, and their esters, phenolic aldehydes, alcohols, and ketones), terpenoids, steroids, amino acids, and inorganic compounds (Dimov et al., 1991; Volpert and Elstner, 1993; Moreno et al., 2000). Many biological properties, including antibacterial, (Mochida et al., 1985; Velikova et al., 2000), antifungal (Dimov et al., 1991; Murad et al., 2002), antiviral (Amoros et al., 1992; Amoros et al., 1994), anti-inflammatory (Strehl et al., 1994; Miyataka et al., 1997), antioxidant (Sun et al., 2000; Isla et al., 2001), hepatoprotective (Gonzales et al., 1995) and immunostimulating (Dimov et al., 1991) activities have been ascribed to propolis. Antibacterial activity of propolis is reported to be due to flavonoids, aromatic acids, and its esters. The biological properties of propolis are attributed to a synergism between phenolic and other compounds in the resin (Burdock, 1998). Therefore, the present study investigated the general composition including total flavonoid and phenolic contents, heavy metals, colors, amino acids, and crude lipid on the south Korean propolis. The propolis collected from the whole part of South Korea, such as central, southern and Jeju island. 


\section{Materials and Methods}

\section{Propolis samples}

The propolis samples collected by Apis mellifera were obtained from the whole part of Korea peninsula, such as middle(Suwon, Yeoju, Yeongwol, Hongcheon, Dangjin, Daejeon, Chungju, Danyang), southern region(Daegu, Mungyeong, Jinju, Changnyeong, Jeonju, Namwon, Gurye, Hwasoon) and Jeju island.

The crude propolis samples were ground into a fine powder, and $5 \mathrm{~g}$ of the propolis powder was mixed with $50 \mathrm{ml}$ of $80 \%$ Ethanol in a test tube and shaken at RT for 48 hours. After extraction, the mixture was centrifuged to obtain the supernatants, which were designated as an ethanol extract of propolis(EEP). The EEPs were lyophilized, which were used to analyze for total phenolic contents and amino acids, the total flavonoid contents, heavy metals and crude lipids.

\section{Determination of total flavonoids concentration}

Flavonoids concentration was determined as follows: $\operatorname{EEP}(0.1 \mathrm{mg})$ was extracted with $90 \%$ aqueous ethanol (20 ml), and centrifuged(3000 rpm, $10 \mathrm{~min})$. Supernatant was collected, the residue was extracted with $80 \%$ ethanol $(8 \mathrm{ml})$, three times, total supernatants volumes were $50 \mathrm{ml}$ with $80 \%$ ethanol.

An aliquot of $0.5 \mathrm{ml}$ was added to test tubes containing $0.1 \mathrm{ml}$ of $10 \%$ aluminum nitrate, $0.1 \mathrm{ml}$ of $1 \mathrm{M}$ aqueous potassium acetate, $1.5 \mathrm{ml}$ of ethanol and $2.8 \mathrm{ml}$ of distilled water. After $40 \mathrm{~min}$ at room temperature, the absorbance was determined spectrophotometrically at $415 \mathrm{~nm}$ on a Perkin-Elmer Lambda 10 UV/VIS Spectrophotometer. Total flavonoid concentration was calculated using quercetin as standard (Moreno et al., 2000).

\section{Determination of total phenolic contents}

The amount of total phenolic in the extracts was determined according to a modification of the Folin-Ciocalteu method (Kuyala et al., 2000). A $0.5 \mathrm{ml}$ aliquot of diluted extract (extract-80\% ethanol, 1:5000 (w/v), three replicates) was introduced into a test tube and mixed with $0.5 \mathrm{ml}$ of $1 \mathrm{~N}$ Folin-Ciocalteu's reagent. The mixture was allowed to stand for a 2 to $5 \mathrm{~min}$ period which was followed by the addition of $0.5 \mathrm{ml}$ of $10 \% \mathrm{Na}_{2} \mathrm{CO}_{3}$. After $50 \mathrm{~min}$ incubation at room temperature, the mixture was centrifuged for $10 \mathrm{~min}(150 \mathrm{~g})$ and the absorbance of the supernatant was measured at $760 \mathrm{~nm}$ on a Perkin-Elmer Lambda 10 UV/VIS Spectrophotometer. The total phenolic content was expressed as gallic acid equivalents (GAE) in milligrams per gram dry material.

The heavy metals contents

The metal(Cadmium, Chrome, Copper, Nickel, Lead,
Zinc, Arsenic, Mercury) concentrations of the propolis were determined using a ICP-MS(Agilent 7500a), the samples for analysis of heavy metal content were degraded with ternery solution.

\section{Amino acids analysis}

Approximately $5 \mathrm{mg}$ of the EEP extract was dissolved in $0.5 \mathrm{ml}$ of $80 \%$ ethanol, added in $0.5 \mathrm{ml}$ of $12 \mathrm{~N} \mathrm{HCl}$ and evacuated in a vacuum hydrolysis glass tube (Kontes, Vineland, NJ). Traces of oxygen were replaced by repeated flushing with nitrogen. The closed tube was heated at $110^{\circ} \mathrm{C}$ for 24 hours to achieve complete hydrolysis. The solvent was removed in vacuo. at $40^{\circ} \mathrm{C}$, and applied to an amino acid analyzer (Pharmacia Biotech System Biochrom 20 Plus type amino acid analyzer) after filtering.

\section{The crude lipid}

The crude lipid was weighed extracted lipid of propolis. Triplicate samples from crude propolis were weighed to $3.0 \mathrm{~g}$ and crude lipids were extracted in ether (Poon et al., 1956).

Table 1. Total flavonoids and phenolic contents of Korean propolis

\begin{tabular}{|c|c|c|c|c|c|}
\hline & \multirow{3}{*}{ Region } & \multicolumn{2}{|c|}{$\begin{array}{c}\text { Total flavonoids } \\
\text { contents }\end{array}$} & \multicolumn{2}{|c|}{$\begin{array}{l}\text { Total phenolic } \\
\text { contents }\end{array}$} \\
\hline & & \multirow[b]{2}{*}{$(\%)$} & \multicolumn{3}{|c|}{$(\mathrm{g} / 100 \mathrm{~g}$} \\
\hline & & & Average & $\begin{array}{l}\text { gallic } \\
\text { acid) }\end{array}$ & Average \\
\hline \multirow{8}{*}{ Middle } & Suwon & 5.37 & \multirow{8}{*}{4.26} & 19.78 & \multirow{8}{*}{13.05} \\
\hline & Yeoju & 4.33 & & 13.79 & \\
\hline & Yeongwol & 5.22 & & 7.97 & \\
\hline & Hongcheon & 2.60 & & 11.91 & \\
\hline & Dangjin & 6.67 & & 13.69 & \\
\hline & Daejeon & 4.72 & & 12.77 & \\
\hline & Chungju & 2.49 & & 10.21 & \\
\hline & Danyang & 2.67 & & 14.25 & \\
\hline \multirow{8}{*}{ Southern } & Daegu & 2.95 & \multirow{8}{*}{2.53} & 9.65 & \multirow{8}{*}{10.91} \\
\hline & Mungyeong & 1.44 & & 9.18 & \\
\hline & Jinju & 3.44 & & 11.10 & \\
\hline & Changnyeong & 2.08 & & 9.51 & \\
\hline & Jeonju & 2.08 & & 12.27 & \\
\hline & Namwon & 1.76 & & 7.84 & \\
\hline & Gurye & 3.34 & & 14.57 & \\
\hline & Hwasoon & 3.16 & & 14.45 & \\
\hline \multirow{3}{*}{ Jeju } & Jeju 1 & 0.08 & \multirow{3}{*}{0.03} & 4.42 & \multirow{3}{*}{7.22} \\
\hline & Jeju 2 & 0.00 & & 12.05 & \\
\hline & Jeju 3 & 0.00 & & 5.18 & \\
\hline
\end{tabular}


Table 2. Heavy metal contents of Korean propolis

(unit : ppm)

\begin{tabular}{|c|c|c|c|c|c|c|c|c|c|}
\hline \multicolumn{2}{|c|}{ Region } & $\mathrm{Cd}$ & $\mathrm{Cr}$ & $\mathrm{Cu}$ & $\mathrm{Ni}$ & $\mathrm{Pb}$ & $\mathrm{Zn}$ & As & $\mathrm{Hg}$ \\
\hline \multirow{7}{*}{ Middle } & Suwon & ND & ND & ND & ND & ND & 0.301 & ND & ND \\
\hline & Yeoju & 0.008 & ND & ND & 0.019 & 0.184 & 0.315 & ND & ND \\
\hline & Yeongwol & ND & ND & 0.027 & 0.001 & 0.114 & 0.402 & ND & ND \\
\hline & Dangjin & ND & ND & ND & ND & ND & 0.256 & ND & ND \\
\hline & Daejeon & ND & ND & ND & ND & 0.013 & 0.265 & ND & ND \\
\hline & Chungju & ND & ND & ND & ND & ND & 0.848 & ND & ND \\
\hline & Danyang & ND & ND & ND & ND & ND & 0.354 & ND & ND \\
\hline \multirow{8}{*}{ Southern } & Daegu & ND & ND & 0.001 & 0.067 & ND & 0.672 & ND & ND \\
\hline & Mungyeong & ND & ND & ND & ND & 0.010 & 0.445 & ND & ND \\
\hline & Jinju & ND & ND & 0.016 & 0.002 & 0.070 & 0.449 & ND & ND \\
\hline & Changnyeong & ND & ND & ND & ND & 0.403 & 0.280 & ND & ND \\
\hline & Jeonju & ND & ND & ND & 0.001 & ND & 0.229 & ND & ND \\
\hline & Namwon & ND & ND & 0.130 & 0.004 & 0.089 & 0.579 & ND & ND \\
\hline & Gurye & ND & ND & 0.053 & ND & 0.017 & 0.515 & ND & ND \\
\hline & Hwasoon & ND & ND & ND & ND & ND & 0.242 & ND & ND \\
\hline \multirow{3}{*}{ Jeju } & Jeju 1 & ND & ND & 0.014 & 0.001 & 0.159 & 0.651 & ND & ND \\
\hline & Jeju 2 & ND & ND & 0.016 & 0.028 & 0.269 & 0.507 & ND & ND \\
\hline & Jeju 3 & 0.018 & ND & 0.021 & 0.013 & 0.538 & 0.600 & ND & ND \\
\hline
\end{tabular}

* ND : Not Detected

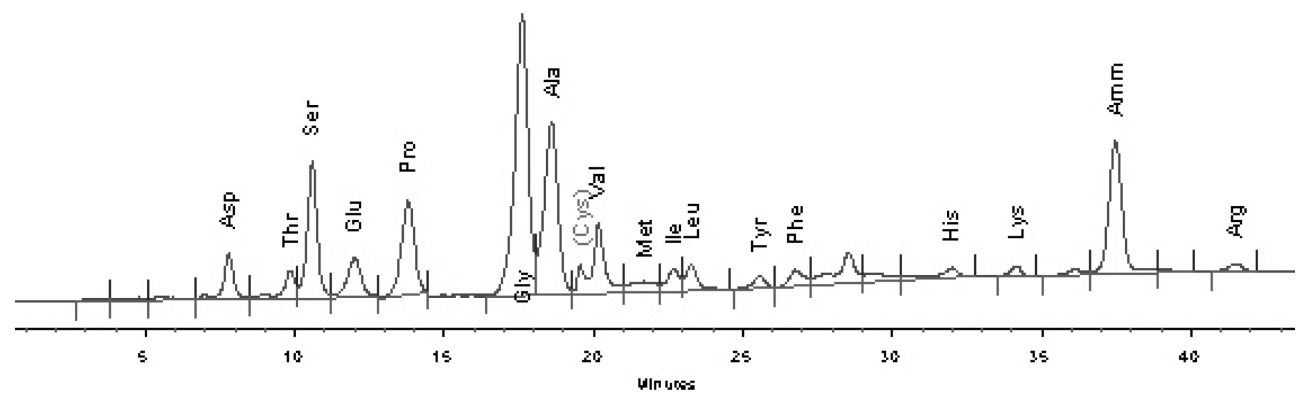

Fig. 1. Amino acids spectrum of Jeju island.

\section{Results}

To analyze the characteristics of Korean propolis according to the region of Korean peninsula, total flavonoids and phenolic contents were measured(Table 1). Total flavonoids and phenolic contents of middle region in Korean peninsula (4.26\% and $13.05 \mathrm{~g} / 100 \mathrm{~g}$ gallic acid) were higher than southern region $(2.53 \%, 10.9 \mathrm{~g} / 100 \mathrm{~g}$ gallic acid) and Jeju island $(0.03 \%, 7.22 \mathrm{~g} / 100 \mathrm{~g}$ gallic acid), respectively. Our results demonstrate that the qualities and quantities of flavonoids are different among the regional provinces of Korea.

A comparative study of total phenolic content of the propolis was undertaken. Total phenolic contents appeared similarly as those of flavonoids did. Moreno et al.(2000) reported that total flavonoids content of Argentine propolis was 1 to $4 \%$. In our studies, the flavonoids and phenolic contents of Korean propolis which collected from middle region of Korean peninsula was higher than Argentine propolis. These meant quantity and quality of Korean propolis were similar or even superior than Argentine propolis.

Although several propolis were collected in Korea contained $\mathrm{Pb}$, they were less than 1 ppm(Table 2), we concluded that Korean propolis would be suitable for the sources of health food because a harmful heavy metal including $\mathrm{Cr}$, As and $\mathrm{Hg}$ were not detected at all in our experiments. On the other hand, $\mathrm{Zn}$ contents were found in $0.44 \pm 0.2 \mathrm{ppm}$.

While various amino acids(Table 3 ) including aspartic 
Table 3. Amino acids content of Korean propolis

\begin{tabular}{|c|c|c|c|c|c|c|c|c|c|c|c|c|c|c|c|c|c|c|}
\hline & egion & Asp & Thr & Ser & Glu & Gly & Ala & Cys & Val & Met & Ile & Leu & Tyr & Phe & His & Lys & Arg & Pro \\
\hline \multirow{7}{*}{ Middle } & Suwon & 0 & - & $\bigcirc$ & 0 & 0 & 0 & $\bigcirc$ & 0 & 0 & - & 0 & $\bigcirc$ & - & - & - & 0 & 0 \\
\hline & Yeoju & 0 & - & 0 & 0 & 0 & $\bigcirc$ & $\bigcirc$ & $\bigcirc$ & 0 & - & 0 & 0 & . & - & - & - & 0 \\
\hline & Yeongwol & $\bigcirc$ & - & 0 & 0 & 0 & - & $\bigcirc$ & $\bigcirc$ & $\bigcirc$ & - & 0 & - & - & 0 & 0 & 0 & 0 \\
\hline & Dangjin & $\bigcirc$ & 0 & 0 & 0 & 0 & - & $\bigcirc$ & $\bigcirc$ & $\bigcirc$ & - & 0 & - & - & 0 & 0 & 0 & 0 \\
\hline & Daejeon & $\bigcirc$ & - & 0 & 0 & 0 & $\bigcirc$ & $\bigcirc$ & 0 & 0 & - & - & $\bigcirc$ & - & - & - & 0 & 0 \\
\hline & Chungju & $\bigcirc$ & $\bigcirc$ & 0 & 0 & 0 & 0 & $\bigcirc$ & $\bigcirc$ & $\bigcirc$ & 0 & 0 & 0 & - & 0 & 0 & 0 & 0 \\
\hline & Danyang & $\bigcirc$ & 0 & 0 & 0 & 0 & 0 & 0 & 0 & 0 & 0 & 0 & 0 & - & 0 & 0 & 0 & 0 \\
\hline \multirow{8}{*}{ Southern } & Daegu & 0 & 0 & 0 & 0 & 0 & 0 & 0 & 0 & 0 & 0 & 0 & 0 & - & - & 0 & 0 & 0 \\
\hline & Mungyeong & 0 & 0 & 0 & 0 & 0 & 0 & 0 & 0 & 0 & 0 & 0 & 0 & - & - & 0 & 0 & 0 \\
\hline & Jinju & 0 & - & 0 & 0 & 0 & 0 & 0 & 0 & $\bigcirc$ & - & - & - & - & - & - & - & 0 \\
\hline & $\begin{array}{l}\text { Chang- } \\
\text { nyeong }\end{array}$ & 0 & - & $\bigcirc$ & $\bigcirc$ & 0 & $\bigcirc$ & $\bigcirc$ & $\bigcirc$ & $\bigcirc$ & $\bigcirc$ & $\bigcirc$ & 0 & - & $\bigcirc$ & $\bigcirc$ & $\bigcirc$ & $\bigcirc$ \\
\hline & Jeonju & 0 & - & 0 & 0 & 0 & - & $\bigcirc$ & 0 & 0 & $\bigcirc$ & - & - & - & - & - & - & 0 \\
\hline & Nam won & 0 & - & 0 & 0 & 0 & 0 & 0 & 0 & O & - & - & - & - & - & - & - & 0 \\
\hline & Gurye & 0 & - & 0 & 0 & 0 & 0 & 0 & 0 & 0 & 0 & 0 & 0 & - & - & - & - & 0 \\
\hline & Hwasoon & 0 & - & 0 & 0 & 0 & 0 & 0 & 0 & 0 & - & 0 & 0 & - & - & - & - & 0 \\
\hline \multirow{3}{*}{ Jeju } & Jeju 1 & 0 & 0 & 0 & 0 & 0 & 0 & 0 & $\bigcirc$ & 0 & 0 & 0 & 0 & - & - & 0 & - & 0 \\
\hline & Jeju 2 & 0 & 0 & 0 & 0 & 0 & 0 & 0 & 0 & 0 & - & 0 & - & 0 & - & 0 & 0 & 0 \\
\hline & Jeju 3 & 0 & 0 & 0 & 0 & 0 & 0 & 0 & 0 & $\bigcirc$ & 0 & 0 & $\bigcirc$ & - & - & 0 & 0 & 0 \\
\hline
\end{tabular}

$\mathrm{d}:$ detected, - : not detected

Table 4. The crude lipid contents of Korean propolis

\begin{tabular}{|c|c|c|c|}
\hline \multicolumn{2}{|c|}{ Region } & $\begin{array}{c}\text { Crude lipid } \\
(\%)\end{array}$ & Average \\
\hline \multirow{8}{*}{ Middle } & Suwon & 54.0 & \multirow{8}{*}{45.1} \\
\hline & Yeoju & 45.2 & \\
\hline & Yeongwol & 53.8 & \\
\hline & Hongcheon & 37.3 & \\
\hline & Dangjin & 50.2 & \\
\hline & Daejeon & 51.6 & \\
\hline & Chungju & 34.5 & \\
\hline & Danyang & 34.1 & \\
\hline \multirow{8}{*}{ South } & Daegu & 43.4 & \multirow{8}{*}{39.7} \\
\hline & Mungyeong & 33.8 & \\
\hline & Jinju & 57.3 & \\
\hline & Changnyeong & 38.4 & \\
\hline & Jeonju & 36.1 & \\
\hline & Namwon & 27.7 & \\
\hline & Gurye & 41.3 & \\
\hline & Hwasun & 39.4 & \\
\hline \multirow{3}{*}{ Jeju } & Jeju 1 & 20.7 & \multirow{3}{*}{27.0} \\
\hline & Jeju 2 & 31.0 & \\
\hline & Jeju 3 & 29.3 & \\
\hline
\end{tabular}

acid(Asp), serine(Ser), glutamic acid(Glu), glycine(Gly), cystein(Cys), proline(Pro), valine(Val), and methionine(Met) were detected in propolis of all area, phenylalanine(Phe) was detected in only Jeju propolis. That means uniqueness of Jeju region which is separated by channel and which might have a unique race of source plants. Finally, the average crude lipid contents(table 4) of propolis were $45.1 \%$ and $39.7 \%$ in middle and southern region, respectively and that of Jeju region were $27 \%$.

In conclusion, the central and southern region propolis are similar, but shows a lot of difference in Jeju Island. These results shows the general characteristics of propolis originates from the vegetation, the southern and central regions are similar vegetation, but Jeju Island due to different vegetation compared with inland areas.

\section{Acknowledgement}

This research was supported by the Rural Development Administration, Republic of Korea.

\section{References}

Amoros, M, Simoes CMO, Girre L, Sauvager F, Cormier M 
(1992) Synergistic effect of flavones and flavonols against Herpes simplex virus type 1 in cell culture. Comparison with the antiviral activity of propolis. J. of Natural Products 55, $1732-1740$.

Amoros, M, Lurton E, Boustie J, Girre L, Sauvager F, Cormier M (1994) Comparison of the anti-Herpes simplex virus activities of propolis and 3-methyl-butyl-2-enyl caffeate. J. of Natural Products 57, 644-647.

Burdock, GA (1998) Review of the biological properties and toxicity of bee propolis. Food and Chemical Toxicology 36, 347-363.

Dimov, V, Ivanovska N, Manolova N, Bankova V, Nikolov N, Popov S (1991) Immunomodulatory action of propolis. Influence on anti-infectious protection and macrophage function. Apidologie 22, 155-162.

Ghisalberti, EL (1979) Propolis: a review. Bee World 60, 5984.

Gonzales, R, Corcho I, Remirez D, Rodriguez S, Ancheta O, Merino N, Gonzales A, Pascual C (1995) Hepatoprotective effects of propolis extract on carbon tetrachloride-induced liver injury in rats. Phytotherapy Research 9, 114-117.

Isla, MI, Moreno MIN, Sampietro AR, Vattuone MA (2001) Antioxidant activity of Argentina propolis extracts. J. of Ethnopharmacology 76, 165-170.

Kujala, TS, Loponen JM, Klika KD, Pihlaja K.(2000) Phenolics and Betacyanins in Red Beetroot (Beta vulgaris) Root: Distribution and Effect of Cold Storage on the Content of Total Phenolics and Three Individual Compounds. J. of Agriculture Food Chemistry 48, 5338-5342.

Markham, KR, Mitchell KA, Wilkins AL, Daldy JA, Lu Y (1996) HPLC and GC-MS Identification of the major organic constituents in New Zealand propolis. Phytochemistry 42, 205-211.

Miyataka, H, Nishiki M, Matsumoto H, Fujimoto T, Matsuka
M, Satoh T (1997) Evaluation of propolis. I. Evaluation of Brazilian and Chinese propolis by enzymatic and physicochemical methods. Biol Pharm Bull 20, 496-501.

Mochida, S, Haga M, Takino Y (1985) Chemical constituents and antimicrobial activity of Japanese propolis. Apimondia. In The XXXth International Apicultural Congress, NagoyaJapan, 455-456.

Moreno, MIN, Isla MI, Sampietro AR, Vattuone MA (2000) Comparison of the free radical-scavenging activity of propolis from several regions of Argentina. J. of Ethnopharmacology $71,109-114$.

Murad, JM, Calvi SA, Soares AM, Bankova V, Sforcin JM (2002) Effects of propolis from Brazil and Bulgaria on fungicidal activity of macrophages against Paracoccidioides brasiliensis. J. of Ethnopharmacology 79, 331-334

Poon, PWB, Durance T, Kitts DD (2001) Composition and retention of lipid nutrients in cooked ground beef relative to heat-transfer rates. Food Chemistry 74, 485-491.

Strehl, E, Volpert R, Elstner EF (1994) Biochemical activities of propolis extracts. III. Inhibition of dihydrofolate reductase. Zeischrift für Naturforschung 49c, 39-43.

Sun, F, Hayami S, Haruna S, Ogiri Y, Tanaka K, Yamada Y, Ikeda K, Yamada H, Sugimoto H, Kawai N, Kojo S (2000) In vivo antioxidative activity of propolis evaluated by the interaction with vitamin $\mathrm{C}$ and vitamin $\mathrm{E}$ and the level of lipid hydroperoxides in rats. J. of Agricultural and Food Chemistry 48, 1462-1465.

Velikova, M, Bankova V, Tsvetkova I, Kujumgiev A, Marcucci MC (2000) Antibacterial ent-kaurene from Brazilian propolis of native stingless bees. Fitoterapia 71, 693-696.

Volpert, R, Elstner EF (1993) Biochemical activities of propolis extracts. II. Photodynamic activities. Zeischrift für Naturforschung 48c, 858-862. 